\title{
Model Of Multiliteracy Education Based On Participatory Rural Appraisal (Pra) For The Rural Society To Increase Independence
}

\author{
Mintarsih Arbarini, Subyantoro \\ Jurusan Pendidikan Luar Sekolah, Fakultas Ilmu Pendidikan,Universitas Negeri Semarang \\ Kota Semarang, Indonesia \\ Email: mintarsih@mail.unnes.ac.id
}

\begin{abstract}
This study aims to describe and develop a model of multiliteracy education based on Participatory Rural Appraisal (PRA) in rural society to increase the independence. The model of literacy education, learners participate in represent theirselves, fulfill their needs, and formulate its own objectives to be achieved, to express and take decisions of learning activities by discussion. The method is the development research. Instruments and data collection techniques are using interview, observation, documentation, and forum discussion (FGD). Subjects of the research are learners, tutors and managers of literacy education. The validity test use a credibility, dependability, confirmability, and transferability. The descriptive qualitative was used in this study. The results show the literacy education can improve the basic of literacy includes reading, writing, speaking, listening, numeracy, and the improvement of economic learners. The necessity of literacy based on PRA include economic, media, health and cultural literacy. It takes a harmonious cooperation between tutor, manager, society, and stakeholders in the implementation of literacy education. This model can help the rural society in assessing and solving the problems in their daily life and to increase the independence of the society itself.
\end{abstract}

Keywords-multiliteracy, PRA, rural society, independence

\section{INTRODUCTION}

Literacy as an educational effort has become a global discourse, because the literacy rate is one that determines the human development index. In 2010, UNESCO as an international organization which working in the field of education, science, and culture proclaimed a movement against illiteracy internationally. The aim is to encourage the entire International community to participate in combating the illiteracy in their respective countries. Indonesia is one of the country with illiteracy is the biggest and as part of the majority of the countries which joined as a member of UNESCO have signed an agreement to implement the Education for All (Education for All/EFA) which is an agreed level of a world created in 1990 in Jomtien, Thailand and reinforced in Dakar, Senegal, Africa in 2000 .

Indonesia's illiterate population aged 15 years and over in 2003 was 8,2 million, then in 2015 was $6 \%$. Based on residence, the proportion of rural residents have higher illeteracy.This situation is consistent for all age groups. Rural women aged 25 years and over are a component of the population that has a high illiteracy rate [1]. Generally, they are small farmers, workers, fishermen, poor people whose level of income are very low. Illiterate rural communities left behind in the field of knowledge, skill and mental attitude of renewal and development.Because of the lack of knowledge, they left behind in gaining access to information and communication is essential to open up the world of life that they are supposed to get a result do not have the literacy skills. To that end, the Indonesian government tried to reduce them through a variety of ways, one of them by accelerating the eradication of illiteracy.

Literacy skills open the opportunities for every individual to know the surrounding world, to understand the various factors that affect the environment, actively participate in national development and democratic life, and to strengthen their cultural identity [1]. Adult population with adequate literacy levels have a greater opportunity to participate in the working world, active in democratic life and volunteer activities, and has a degree of good health and high levels of income. The Indonesian government is required to complete the illiterate people because since 2008 and has joined the LIFE program (literacy initiative for empowerement).

However, the development of Indonesia's rural communities are growing rapidly and complex society requires a commitment to constantly learn, follow and anticipate the development progress. No exception the literacy shift in not only single literacy or basic literacy needed by the community, but rural communities have begun requiring dual or multiliteracy. This is because in order to enter the 21 st century meaning of literacy become more widespread, not just reading, writing, and arithmetic, but the concept is more extensive and evolving to respond to changing patterns of communication that is growing through multiliteracy. Multiliteracy may include economic literacy, health literacy, social literacy, information literacy, technology literacy, civic literacy, and critical literacy.

In Global Literacy Challenge, UNESCO believes that it should significance of literacy is not narrowed only with basic literacy, but as the ability to identify, understand, interpret, create, communicate with the involvement of a continuum of learning that enable people to achieve goals and develop their knowledge and potential, to participate fully in the community wide community. To that end, education of multiliteracy which today is very appropriate to be applied in advance of society, especially in rural communities. 


\section{RESEARCH METHODS}

Based on the analysis of the findings of previous studies [2] the main obstacle in the lack of independence rural communities because the government still dominates the literacy education through programs that cater to the community. Literacy programs that have been held in the community include functional literacy, independent business literacy, mother tongue-based literacy, local culture literacy, and entrepreneurship literacy. The literacy program has actually been successfully implemented, but still has shortcomings, one of them is if the program and the funds that have been awarded completed then the program stopped anyway. According [3] two factors are linked to the attainment of literacy, namely primary education and adult literacy education. Drop-out of primary school with reading skills so they cause less adult illiteracy and adult illiteracy in time will produce children who are not educated.

On the other hand, the study of [4] states that the tutor who has limited ability literacy learning by using learning direction. There is no tutor is able to manage the natural potential of the source and learning materials. Natural potentials have not been analyzed and identified so that it has been added value to the learning process as well as economically. The result from [5] states that the implementation of literacy in literacy for youth and adults in rural communities are still many experienced weakness in academic and methodological aspects.

To overcome the problems above, the study of [6] shows that the learning techniques with participatory rural appraissal (PRA) at the adult learning rural communities effectively used not only to improve learning outcomes, but also to develop an attitude and learning achievement. Subsequently [7] in his study concludes that the application process of PRA in empowering rural communities have the result more than $80 \%$ of the 95 participants give positive response toward the implementation of partisipative learning.

The process of Multiliteracy education learning will be more meaningful if people are active in the whole process both mentally and physically. Therefore, learning model should provide an opportunity for citizens to learn to search, process and find their own knowledge so that learners can develop the basic skills of knowledge. On PRA-based education model multiliteracy residents of rural communities are invited to perceive themselves, needs, and formulate its own objectives to be achieved as well as participate expressed or taking decisions and learning activities through consultation between residents learned society with a tutor.

This study aims to describe the implementation of literacy education held during this time on rural communities, supporting factors and inhibitors, multiliteracy education needs of rural communities, and the design of multiliteracy education model based on participatory rural appraisal. The description indicates that it needs efforts to increase the independence of rural communities to always have a high dependence on literacy education programs of the government applied by a top-down project. To that end, the educational model multiliteracy used as a study in this research is based PRA multiliteracy education model to enhance the independence of rural communities.

\section{A. Types of Research}

This study uses research and development approach [7]. Selection of the type of research and development based on the consideration of research and development is to produce the products based PRA multiliteracy education model for rural communities to enhance the independence of a procedure. For the needs of this research, it is adapted to the purpose and conditions of the actual research.

\section{B. . Research Subject}

The subject of research is selected purposively dealing with the objectives. The subjects are managers, tutors and learners multiliteracy education of rural communities in the district of Semarang. The number of this study groups of in Semarang District consisted of three study groups. Each study group contains 15-20 people learners, two tutors, and 2 organizers. The focus of this group discussion consists of the experts from non-formal education, linguists, and literacy practitioners which aims to verify the designed models.

\section{Instruments and Data Collection Techniques}

The instruments and techniques used to collect data is an instrument of interview, observation and documentation. The data collection is done by examining the data from interviews, observation, and documentation is descriptive qualitative. Data collection techniques in this study were taken directly by the researchers of the subject directly. The data were obtained through focus group interview guide instrument that aims to get an overview and maximum and complete results.

\section{Data Analysis}

In this study, the data analysis phase of preliminary studies conducted by examining data from interviews, observation, and documentation is descriptive qualitative [8]. Data analysis started during the data collection process, do data reduction, data presentation, and ended by drawing conclusions and verification. Based on the results of theoretical study of theory and field data analysis by descriptive qualitative, then used to develop a conceptual model of education multiliteracy participatory rural appraisal based on rural communities. Prototype models verified by conducting focus group discussions involving the experts, practitioners, and researchers.

\section{RESULT AND DISCUSSION}

\section{A. RESULT OF THE RESEARCH}

1) The Implementation of Literacy Education toward Rural Societies

Literacy education program which had been held for rural societies learning group in Semarang regency in this research was functional literacy education (FLE). The average age of these learning communities was 40-55 years. By the total amount of people in each group were 15-20 people. This research took place in three locations, those were, one learning group Ngudi Kaweruh from Candi Garon village, subdistrict 
Sumowono, Semarang regency. The second group was from Warung Pasinaon learning group, from Bergas Lor village, Bergas subdistrict Semarang regency, and the third group was Belajar Uswatun Khasanah group from Jombor village, subdistrict Tuntang, Semarang regency.

The occupation had by the learning communities who became students of this literacy education program from Ngudi Kaweruh learning group were farmworkers and green grocery sellers. In Warung Pasinaon learning group their occupations were housekeepers, farmers, and food sellers. Almost of all people from Uswatun Khasanah learning group were scavengers and housewives. All of these learning communities had been followed the functional literacy education (FLE), so that they had been able to read, write, calculate, listen, and speak in Indonesian. Those three learning groups studied in their tutor's house, twice a week and 2 hours in each meeting.

The learning proses consisted of three aspects, they were planning, learning, and evaluating. In planning stage, it was started by the identification of needs activity as the beginning of learning plan. Identification of needs had not engaged the people yet. Identification of students' need was still conducted by the tutor without engaging the students. Thus, the determination of learning material was only done by the tutor so that sometimes it was not appropriate with students' needs.

In learning stage of literacy education for rural societies learning group in Semarang regency was described as follows. The learning process was started by the initial preparation before learning activity was held by doing socialization and giving information about the material which would be studied. The first step was the tutor prepared the administration including student's attendance list, lesson plan, and evaluation system. The learning materials including: reading, writing, listening, and numeracy which were integrated by functional skill. Learning evaluation was done by (a) pre-learning evaluation, (b) learning process evaluation, (c) post-learning evaluation. Basically, evaluation was done for these aspects (a) reading, (b) writing, (c) numeracy, (d) speaking, (e) listening, and (f) skill. The implementation of these evaluations had not been held yet in a program, consistent, and systematic way. But still, for the students who had been graduated from the literacy education they got SUKMA (certificate of literacy) certificate.

The determination of learning materials was based on the result of identification of learning's needs and it was formulated by the tutor himself, so that sometimes the learning materials had not been appropriate with the students' needs. In formulating the purpose of the literacy learning it referred to lattice which had been composed by the government used literacy competence standard (LCS)/literacy competence standard (SKK). The learning materials in literacy education consisted of reading, writing, numeracy, speaking, and listening and it was added by skill. But, the skill which was taught was just what the tutor mastered. Besides, the learning groups could not make their own materials based on their needs, so that the materials used in the learning process still used the materials provided by the government

Based on the observation, students' literacy learning in listening skill was taught by tutor by making literacy passage through these steps: 1) tutor prepared a passage, 2) tutor chose students to read the passage which was prepared, 3) other students listened/observed what tutor read, 4) tutor asked students what the passage was about, 5) students retold the content of the passage, 6) tutor assessed the listening skill based on the skill of retelling a passage which was read by tutor.

Literacy learning in speaking was taught by these steps: 1) tutor showed pictures to the students, 2) tutor asked them what moral values were on the pictures, 3 ) tutor asked them to retell the moral values contained in the pictures which was showed by the tutor, 5) tutor assessed students' speaking skill from their skill in retelling.

The activity of reading in literacy learning was taught by these steps: 1) tutor provided a story related to the students, 2) students began to read it, 3) tutor assessed students' reading skill especially from the use of punctuation. The activity of writing in literacy leaning was taught by these steps: 1) tutor asked the students to write a letter, write a blanc form, 2) tutor assessed students' writing skill trough their writing works.

Literacy learning in numeracy was taught by these steps: 1) tutor made questions related to calculation, by doing four equation symbols (plus, minus, multiplication, and division), 2) the questions were made in a story, 3 ) tutor asked students to answer the questions, 4) tutor assessed students' calculation skill. Score data from the students' assessment test related to listening, speaking, reading, writing, and numeracy data then they were interpreted qualitatively based on the table of quality standard by the score 50-60 was categorized as poor, 61-70 was medium, 71-80 was fair, 81-90 was good, 91-100 was excellent. All of the students from three learning groups had done the functional literacy education and got SUKMA certificates.

Based on the explanation above, it shows that the implementation of literacy from the planning, learning and evaluating had not been optimally done because the learning process was still dominated by tutor and students were not engaged.

\section{2) Supporting and obstructing factors of the} implementation of literacy education

Based on the information from interview, observation, and documentation was obtained some data about the condition of objective and problems which happened in the implementation of literacy education. Literacy education which had done in learning groups in Semarang regency had supporting and obstructing factors. The supporting factors in implementing the literacy education in Semarang regency were: 1) commitment and support from village government 2) support from stakeholder and society, 3) the rise of rural societies' interest in literacy education, 4) students' enthusiasm in following the learning activities. In this implementing the literacy education program it got support from village government. It was proved when the recruitment of students, the village officials and tutors visited villagers' houses to get the data and communicate about the importance of literacy education and ask them to follow the literacy education. This was also able to rise rural 
societies' interest and enthusiasm in following the learning process.

The use of expense of this literacy education activity was neat, because the entire source of funds was from direktorat of society education for functional literacy education program relief. That source of funds was managed and adjusted by managing sides. All of the funds was openly coordinated by the operators and tutor.

The literacy education program was followed by rural societies with low social economic. In implementing this literacy education, besides the supporting factors, there were also some obstructing factors as follows: 1) students had a difficulty in dividing their schedules to follow the learning process because almost students' time was used to work. 2) students were not clearly understood enough about the tasks they followed, 3) students' ages were 40 years onward so that it was very difficult to be taught, 4) their lack of understanding toward the importance of education to their live progresses, 5) the lack of materials which could be used to improve students' learning skill.

To overcome those obstructions, village officials or tutors had many efforts to support the program. Those efforts were done until students finished their literacy education and got SUKMA certificates.

\section{3) Rural societies' multiliteracy education needs}

Students' needs in participatory rural appraisal-based multiliteracy education were conducted by deep interview. It was chosen because the lack of students' understanding to know every question. That is why, interview was the appropriate instrument to dig students' needs. Based on the finding, rural societies' multiliteracy needs had three aspects: (a) personal aspect, it was students' incapability in solving problems and realizing their potentials, (b) social aspect, it was tutors' limitation of the information and knowledge about literacy and students' needs, (c) vocational aspect, and it was students' willingness to master literacy and other skills. Based on those three aspects above, multiliteracy education which could be used to solve the problems of rural societies' independences were economic, media, health, and cultural literacy.

Societies' needs related to economic literacy was literacy learning which was integrated with some skills needed by students to increase their family earnings until the business learning group. Societies' needs related to media literacy were literacy learning by teaching students used computers, village's library, and cellular phones to increase their capability in literacy. Besides that, it was also supported by a plan of building a library for literacy students or people around the village.

Health literacy needed by rural societies was literacy learning that was combined by health needs and involved with health officials including village midwives, the officials of posyandu, and posyandu for elders. In cultural literacy was excavation of cultural heritages of the societies. Learning groups in Jombor village, subdistrict Tuntang, Semarang regency needed rebana cultural literacy. Candingaron village, subdistrict Sumowono needed Jaran Eblek as the cultural preservation. Then Bergas Lor village, subdistrict Bergas also chose Jaran Eblek as their cultural literacy need.

By looking at the result of the identification of needs above and considering the local conditions and potentials then the developmental plan was made which was integrated with economic literacy materials including skills, health literacy, media literacy, and cultural literacy. Besides that, the multiliteracy looked at social-cultural aspect and the condition of local economic. Model which was developed covered the reinforcement of basic literacy to be multiliteracy. This multiliteracy model was developed by looking at rural societies and the conditions of societies' social-cultural. Multiliteracy learning was based on PRA rural students were stimulated to make the perceptions of themselves, fill their needs, and formulate their own purposes which they wanted to get and also tell or take the learning activity decision through a discussion between students and tutors.

4) Multiliteracy education model plan used participatory rural appraisal-based (PRA) to increase rural societies' independences

This participatory rural appraisal-based multiliteracy model aimed to increase rural societies' independences in literacy. Students from rural societies who had studied basic literacy (reading, writing, numeracy, and skill) with multiliteracy education model could increase other literacies including media literacy, health literacy, and cultural literacy. This model was also expected to increase societies' independences by doing activities independently through society's library, local arts and mother tongue, routine posyandu, information media service, and business learning groups. For the clear explanation, here the diagram model which was developed.

Participatory rural appraisal-based multiliteracy education model used PRA principles including: 1) give priority to the ignorance (staking side) principle, 2) empowering (reinforcement) society principle, 3) PRA approach to increase societies' skills, 4) PRA make society as the center of development activity and others have to realize their roles as facilitators, 5) relax and informal principle, 6) PRA activity is held in flexible, open, without forcing and informal condition, 7) triangulation principle, 8) optimizing the result principle, 9) continues and time gap principle, and 10) open principle.9].This multiliteracy model was centered on how society used their literacy skills in their daily lives. Societies did not only read the information but applied them and took the benefits to increase their lives' qualities, either materially of physically. Learning materials got from environment either by individual or group could be learned and analyzed, then wrote the plans and proposal to fix the situations. The purpose of multiliteracy learning was to help students find and use their own materials. Therefore, tutors did not only help them read a book, but they also helped students to go to Taman Bacaan Masyarakat (TBM). Tutors also asked informants from other instances to help students. 


\section{DISCUSSION}

Multiliteracy education will be more meaningful if societies engage actively in all of the process both mentally and physically. Therefore, the implementation of multiliteracy education should give a chance to societies to search, process, and find their own knowledge so that students can develop their own basic knowledge skills. This multiliteracy education was started by students' engagement in finding their own needs about what they wanted to learn about. Definition of literacy from UNESCO [11] on literacy "Literacy is as a continuum of learning that enables individuals to develop their knowledge and potential, pursue and achieve their goals, and participate fully in society".

The implementation of literacy education of rural societies' learning group in Semarang regency was started by initial preparation before the learning process by doing socialization and giving information about the materials which would be studied. Learning process consisted by three aspects those were planning, learning, and evaluating. The literacy materials for rural societies' learning group in Semarang regency consisted of: reading, writing, listening, speaking, and numeracy which was integrated with functional skills.

Planning system of multiliteracy education program with PRA was arranged by participative approach, so that it engaged students, tutors, and related instances to determine many things related to the plans of functional post-literacy program. Generally the purpose of the multiliteracy program was to develop literacy education with students' life skills which were integrated with various other skills and used PRA-based approach. This is according to research that PRA is one of the most appropriate approach to identify community problems and to understand the socioeconomic and cultural aspects of society [12]. Next, This study describes the condition of adult literacy in the context of rural communities. Economic conditions, educational opportunities, and resources of rural communities far behind urban communities. To deal with these conditions needed innovative learning opportunities as a strategy in community development through adult literacy. One of the approaches used by the capital social [13].

PRA is a group of approaches or methods which make rural societies possible to share, increase, and analyze their own knowledge about the condition and life of village, and also make plans and real acts [9]. Learning independence and continuous effort were by using local resource potentials but still concern about the preservation of resource and environment. Counseling and developmental activity or the relief to rural target groups was held to make them develop to be steady and independent people and also continuously develop their businesses with the attitude of entrepreneurship. In teaching reading and writing, we have come to accept that literacy is not a stand alone set of skills but social practices influenced by context and culture [14].

Multiliteracy education could be seen as a concept, process, and program. As a concept, multiliteracy education could be seen as a part of lifetime education, adult education, and continuous education. As a part of continuous education, this multiliteracy education tried to give a chance to students who were interested in increasing and developing their own learning potentials after following this literacy program through various kind of economic literacy, media literacy, health literacy, and cultural literacy.

\section{CONCLUSION}

Learning was started by initial preparation before learning process by doing socialization and giving information about the materials which would be studied. Literacy education for rural societies' learning groups in Semarang regency including: reading, writing, listening, speaking, and numeracy.

In implementing the model which was developed it was important to look at the prerequisites and procedures of the implementation of program. Thus, the effectiveness of program which was expected by the operators to be reached. It was done so that the maintenance and/or the increasing of literacy skill which was combined by vocational skill could work effectively.

In multiliteracy education, potential inventory and rural resource, and also documented it well needed cartography officials and social analysis and documenting which were comprehended adaptively by using participatory rural appraisal approach. Besides that, by using media which could be accessed and understood by rural societies made it easy to increase rural societies' independences.

\section{ACKOWLEDGMENT}

The author would like to thank the Ministry of Research and Higher Education to provide funding for this research

\section{REFERENCES}

[1] Kemendikbud. Pendidikan keaksaraan untuk semua. Jurnal AKRAB: Aksara agar berdaya. I, Edisi I/Maret/2010,03-19

[2] Arbarini, Mintarsih. Pengembangan Bahan ajar pendidikan keaksaraan Usaha Mandiri di PKBM Kabupaten Semarang. Laporan Penelitian DIPA. 2013.

[3] Yulaelawati, Ella dan Suharti. 2010. Kesenjangan gender di Indonesia: akses terhadap pelayanan pendidikan, hasil belajar, dan ketenagaan. Jurnal AKRAB: Gender dan Pendidikan Perempuan, Volume 1, edisi 4. Desember 2010, 32-49.

[4] Suryadi. Buta aksara penyakit sosial mesti diberantas. Retreived August 30, 2014. www.jurnalnet.com

[5] Kuntoro, S. A. Pendidikan multiliteracy untuk mencerdaskan kehidupan masyarakat. Jurnal Ilmiah VISI PTK-PNF- Vol 2. No 1- 2007, 23-27.

[6] Duze, C.O. Effect of participatory learning technique on achievement and attitude of B. Ed, student in educational research methods. Journals of Social Science, 22,(3), 2010. 185- 189.

[7] Kim, J.R., Jeong, B., Park, K.S., \& Kang Y.S. Application of the participatory learning Process in Health promotion. Journal of Agricultur Media Community Health. Korean. Jun: 36 (2): 2011. 130-142

[8] Gall, M.D., Gall, J.P., \& Borg, W.R. 2007. Educational research:An Introduction. (Eighth edition). United States of America: Pearson Education.

[9] Creswel. John W, Research Design qualitative, quantitative and mixed methods approaches, Third Edition, Sage Publications. Thousand Oaks California, 2009. pp 258.

[10] Chambers, R.. Participatory rural appraisal: memahami desa secara partisipatif (terjemahan Y.Sukoco). 1996. Yogyakarta: Kanisius.

[11] UNESCO. Literacy and empowering people. 2003

[12] Alam, A. \& Ihsan, S. Role of participatory rural Appraisal in Community Development (A Case Study of Barani Area Development 
Project in Agriculture, Live Stock and Forestry Development in Kohat.International journal of Academic Research in Business and Social Sciences. August, 2012, Vol.2. no.8., 25-38.

[13] Ziegler, M. F \& Davis, D. C. (2008). Rural adult literacy in community context: from the margin to the mainstrem. Journal of New Directions for Adult and Continuing Education, no.117, Spring 2008, 25-35.

[14] Williams, Bronwyn T. Tomorrow will not be like today: Literacy and identity in a world of multiliteracies.International Reading Association. Dol:10. 1588/JAAL.51.8.7.pp 682-688.. 